\title{
CUSTOMER ENGAGEMENT IN SOCIAL MEDIA AND TOURISM BRAND PERFORMANCE IMPLICATIONS
}

\author{
Song Bee Lian* \\ Faculty of Business, Accounting and Management, SEGi University, Selangor, Malaysia. \\ * Corresponding Author: blsong@segi.edu.my \\ Liew Chee Yoong \\ Faculty of Business, Accounting and Management, SEGi University, Selangor, Malaysia.
}

\begin{abstract}
The growing popularity of social media (SM) is seen as an avenue for businesses to build relationships with customer. Tourism firms have increasingly adopted customer engagement (CE) strategies in SM to achieve superior firm performance. The investigations on CE in SM have been widely conducted, however little is known about its effect on tourism brand performance outcomes, particularly in Malaysia. This study aims to provide empirically tested nomological framework that places CE in social media as consequences of social interaction, surveillance and attraction, and as an antecedent of tourism brand image and brand loyalty. Data are collected through survey questionnaire from 350 airline and hotel customers who utilizes social media in Malaysia. Structural equation modeling is applied to analyse the data. Results shown that effective CE in social media enhances brand image and loyalty. Surveillance had the greatest positive influence on CE, followed by social interaction and attraction. The theoretical implications include both a conceptual foundation and empirical-based evaluation of $\mathrm{CE}$ through a gamified brand platform. From a pragmatic perspective, this research may aid practitioners in developing more effective CE strategies such as more attractive contents, continuous promotions or rewards, sharing valuable information, and intensity of interactivity to enhance brand performance.
\end{abstract}

Keywords: Customer engagement, Social media, Brand loyalty, Brand image, Brand performance

\section{Introduction}

Brands are highly valuable assets for firms and important to sustain competitive advantage in the market. Customer engagement (CE) has been a domain of research interests with the rise of social media (SM). The increasing attention given by travelers on SM have encouraged tourism service providers to engage customers through various SM platforms. For example, TripAdvisor-branded sites comprise the largest travel community in the world, with more than 390 million unique monthly visitors and have reached more than 500 million reviews and opinions for 7 million accommodations, restaurants, and attractions worldwide (TripAdvisor, 2017).

In today's dynamic marketing environment, firms engage with their customers via free SM delivery platforms such as microblogging (e.g., Twitter), content-sharing communities (e.g., YouTube and Instagram), and social networking sites (e.g., Facebook and LinkedIn. Motivational factors that influence CE in social media from previous studies include content type, media type, and posting time (Cvikikj and Michahelles, 2013); information gratification, fun and entertainment, social interaction value, and co-creation value (De Vries and Carlson, 2014); organisational factors (Wang and Hyun, 2017); practical benefits, social benefits, economic benefits, social enhancement, and entertainment (Gummerus, Veronica, Weman and Pihlström, 2012).

Arora and Predmore (2014) acknowledged four distinct advantages of SM to the firms in the aspect of cost effective in acquiring customer, loyalty, innovativeness and create strategic value. $\mathrm{CE}$ has been used as a key new metric for measuring brand performance (Bowden, 2009). According to Trivedi and Vadher (2010), brand performance can be understood as the value perception by customers. This study will emphasize on consumer-based brand performance measures. The brand performance metrics 
comprising brand loyalty (Kaplan and Norton, 1992; Munoz and Kumar, 2004; Keller and Lehmann, 2003) and brand image (Keller and Lehmann, 2003) which have been widely used in past research studies. De Vries and Carlson (2014) found that positive brand performance outcomes are measured by brand loyalty and brand image in the context of CE with Facebook brand pages.

Despite great attention given by firms to drive SM presence, but the impact of SM on creating desirable brand performance outcomes still remain ambiguous. Furthermore, there is a paucity of literature addressing how effective the Malaysian tourism brands in engaging customers and enhance their relationships with brands to achieve positive brand performance outcomes. Hence, the primary objectives of this study are; 1) to investigate the effect of social interaction, information sharing and surveillance on $\mathrm{CE}$ and 2) to analyse the influence of $\mathrm{CE}$ on brand image and brand loyalty.

\section{Literature Review And Hypotheses Development}

\subsection{Uses and gratifications theory}

The uses and gratifications theory (U\&G) assumes that the media provides several gratifications for the audience that motivates it to consume some media product (Katz, Blumler and Gurevitch, 1974). For example, the capacity of the media product to provide information, provide useful subjects of conversation, entertain, help to escape from reality, support the search of personal identity, and other aspects can be important factors to infuse the audience to consume a specific media product (Burton, 2010). The expectations and gratifications obtained influence individual's behavior of media consumption which in its turn satisfies sought gratifications. As such, the context of this paper focuses on the motives in the form of sought gratifications that could influence customers' engagement on SM pages. The U\&G theory has been applied in many SM studies (Perez, Mafe and Blas, 2014; Whiting and Williams, 2013). The conceptual framework for this study is developed by applying the U\&G theory as it would assist to examine the motivations that induce customers to engage with the tourism brand pages on SM. By examining U\&G theory, this study identified three motivations - information sharing, surveillance, and attraction that have been used by several scholars (Harrigan, Evers, Miles, and Daly, 2017; Perez et al., 2014; Whiting and Williams, 2013) and which can be analysed to see whether they influence CE in SM. Furthermore, we have based on the analysis of the past literature which have drawn the relationship between $\mathrm{CE}$ and brand performance outcomes of brand image and brand loyalty, to develop more comprehensive CE framework.

\subsection{Social Interaction}

Social interaction refers to the motive that pushes us to communicate and interact with others (Whiting and Williams, 2013). SM provide users with interaction platform to meet like-minded others, interact, and communicate with them about specific products or brands (Muntinga, Moorman and Smit, 2011). According to Hollebeek, Glynn and Brodie (2014), social interaction between a customer and an organisation, as well as between customers themselves, is essential for effective CE to strengthen the emotional, psychological or physical investment a customer has in the brand, as well as the organisation. In view that the objective of brand posts is to motivate customers or brand fans to react, such as by liking and/or commenting, and it may lead to more favourable outcomes towards brand image and brand loyalty. For example, Booking.com or TripAdvisor, actively engaged customers through soliciting reviews, transparency or social influence. Hence, the following hypothesis will be tested in this respect:

$H_{1}$ : Social interaction has a positive influence on CE in social media.

\subsection{Surveillance}

Surveillance is defined as "a motive of using media to seek out information or to selfeducate" (Whiting and Williams, 2013). Surveillance relates to keeping up with current happenings and getting an understanding of issues. High quality information obtained by customers made them feel that their interactions are worthwhile (Gummerus et al., 2012). Humphreys and Wilken (2014) assert that as information is available via SM, it creates new opportunities for surveillance and engagement. A customer who need to acquire product information or reduce perceived risks may engage in a brand discussion forum (Brodie, Ilic, Juric and Hollebeek, 2013). Consumers tend to have positive attitudes toward informative advertisement on SM (Taylor, Lewin, and Strutton, 2011) due to 
its transparency and dynamic characteristic. Therefore, to explore the relationship between surveillance and $\mathrm{CE}$, the following hypothesis will be examined:

\section{$H_{2}$ : Surveillance has a positive influence on CE in social media.}

\subsection{Attraction}

The attraction in SM pages refers to the richness of a brand post's formal features (De Vries, Gensler and Leeflang, 2012). The attractiveness of the SM pages involves the extent to which a brand post stimulates the different senses (Steuer, 1992). Usually SM attracts viewers through dynamic animations, colors, or pictures (Cho, 1999). According to Fortin and Dholakia (2005), the more attractive the appearance of the SM websites, the more effective at enhancing attitudes toward a website. Continuous attention given by customers towards a brand may lead to higher levels of engagement (Scholer and Higgins, 2009). Therefore, to test this relationship the following hypothesis is formed:

\section{$H_{3}$ : Attraction has a positive influence on CE in social media.}

\subsection{Customer Engagement}

$\mathrm{CE}$ is defined as "customers' behavioral manifestation toward a brand or firm, beyond purchase, resulting from motivational drivers" (Van Doorn, Lemon, Mittal, Nass, Pick, Pirner and Verhoef, 2010). CE reflects the intensity of an individual's participation in and connection with an organisation's offerings or organisational activities, which either the customer or the organisation initiates (Vivek, Beatty and Morgan, 2012). Hollebeek (2011) conceptualise CE as a process of cognitive, emotional and behavioural. According to So, Sparks and King (2014), CE on brands are divided into five dimensions - identification, enthusiasm, attention, absorption, and interaction. Bowden (2009) believed CE involving the concept of involvement (behavioural) and commitment (cognitive and affective). Cvijikj and Michahelles (2013) measured CE through actions such as page views, click-through rates, and other measures depending on the SM platform. Gummerus et al. (2012) found CE on SM as a combination of frequency of brand community visits, news reading, content liking, commenting, frequency of playing games, and money spent on internet gaming websites. However, CE on SM was not solely measured through specific actions but also through customers' perception of engagement. For example, along with the commonly used parameters such as "liking", "sharing", and "commenting" on brand pages (De Vries et al. 2012). De Vries and Carlson (2014) studied customers' perception of engagement and their beliefs on whether they are integrated, active, and participating on SM brand pages.

\subsection{Brand Image}

Brand image is defined as "perceptions about a brand as reflected by the brand associations held in consumer memory" (Keller, 1993). CE influenced firm's brand image in the context of virtual interactive media (Blasco-Arcas, Hernandez-Ortega and Jimenez-Martinez, 2016). Woisetschläger, Hartleb and Blut, (2008) found that customer participation positively influenced brand image of the community sponsor. In SM, consumers have the flexibility to create their own brand stories and post them in various formats which can be either positive or negative, leads to favoring or damaging a brand's image (Gensler, Völckner, Liu-Thompkins and Wiertz, 2013). The following hypothesis will be examined:

\section{$\mathrm{H}_{4}$ : $\mathrm{CE}$ is directly and positively correlated to the brand image.}

\subsection{Brand Loyalty}

CE plays a significant role in enhancing brand loyalty (Kam, King, Sparks and Wang, 2016; Hollebeek, 2011). In the context of tourism brands, CE has been found positively influenced behavioural intention of loyalty (Harrigan et al., 2017). De Vries and Carlson (2014) reported that CE had influenced brand performance outcomes of CE behaviours directed at the brand page and brand loyalty. They further assert that co-creation value, social value, usage intensity and brand strength influenced CE with brand pages. Kam, King and Sparks (2014) found that CE to exert a positive significant influence on behavioral intention of loyalty for both hotel and airline customers. Khan, Rahman and Fatma (2016) investigated the online CE effect on brand loyalty, and concluded that 
online engagement experience has positively influenced customer loyalty toward the brand. Therefore, to explore the relationship between $\mathrm{CE}$ and brand loyalty, the following hypothesis will be examined:

$H_{5}: C E$ is directly and positively correlated to the brand loyalty.

\section{Research Methodology}

\subsection{Sampling and Measurement}

The population for this study was airline and hotel customers who had traveled domestically or internationally in the past 6 months and residing in the state of Selangor and Federal Territory of Kuala Lumpur, Malaysia. Non-probability convenience sampling method was used to select the sample of 350 respondents who presence at 10 selected hotels in Selangor and Kuala Lumpur. A pilot study was conducted on 100 respondents to ensure respondent's comprehension of the questionnaires. Items to measure the constructs were rated on a 6-point Likert scale, which ranged from $1=$ strongly disagree to $6=$ strongly agree.

\subsection{Validity and Reliability Assessment}

The pilot study comprises the Exploratory Factor Analysis (EFA) to eliminate variables with factor loading $<0.3$. According to Pallant (2007), the Bartlett's Test of Sphericity value should be significant at $\mathrm{p}<0.05$ and Kaiser-Meyer-Olkin (KMO) value should be 0.6 or above. In examining EFA using Maximum Likelihood extraction and Promax rotation, it has yielded six dimensions with KMO score of 0.875 , Bartlett's Test $\mathrm{p}=0.000(\mathrm{p}<0.05)$. The factor loading for all the 27 proposed items is above 0.3 . The Cronbach's Alpha value of the constructs ranged from 0.715 to 0.921 , and exceeded the threshold level of 0.7. High level of internal consistency (Pallant, 2007) in the data and all constructs were valid and reliable for further inferential analyses. The results is shown in Table 1.

\section{Results}

\subsection{Demographic Profile of the Respondents}

The total respondents for this study is 350, comprising 182 female respondents (52\%) and 168 male respondents (48\%). Majority respondents of $45 \%$ belongs to age category between 21 and 39, followed by $30 \%$ between $40-59$. As for the income category, majority respondents of $44 \%$ falls between RM3000 and RM6000, followed by 31\% between RM6000 and RM10000. Majority of respondents come from high educated category which are bachelor degree (48\%) and post-graduate $(15 \%)$.

\subsection{Model Compatibility Testing}

Structural equation modeling (SEM) is applied to measure the proposed research model and test the hypotheses. Overall, the research model has achieved a good fit. The chi-Square value was 706.844 . The ratio of $x^{2} / \mathrm{df}$ was 2.237 . Incremental fit values were greater than 0.9 , with IFI of 0.923 , CFI of 0.923 and TLI of 0.914 . As for the absolute index, RMSEA of 0.060 which was lower than the threshold level of 0.8 .

Table 1: CFA Results for the Measurement Model 
The Turkish Online Journal of Design, Art and Communication - TOJDAC

ISSN: 2146-5193, September 2018 Special Edition, p.1186-1194

\begin{tabular}{|c|c|c|c|c|}
\hline Construct & Item & Statement & $\begin{array}{l}\text { Factor } \\
\text { Loading }\end{array}$ & $\begin{array}{l}\text { Cronbach's } \\
\text { Alpha }\end{array}$ \\
\hline \multirow[t]{5}{*}{ Socid Interacticn } & V1 & Opportunity to know new pecple & 316 & .921 \\
\hline & $\sqrt{2}$ & Easy to share infonmatica with others & 390 & \\
\hline & $\sqrt{3}$ & Easly connect with frieads/ohers & 391 & \\
\hline & $V_{4}$ & Ofen participate in actirities of the tourism site & 338 & \\
\hline & vs & Conversationor ofinion exchange with others & 757 & \\
\hline \multirow[t]{5}{*}{ Survrillans } & C.1 & Prwidegondinfomutirn as servioes & 577 & .954 \\
\hline & C2 & Help me to leam irteresting things & 750 & \\
\hline & C3 & Keep on-to-date wth the latect informaton & 757 & \\
\hline & $\mathrm{CH}$ & Offered customised information search & 316 & \\
\hline & es & Provide informaticn on atestprommotions & $(B)$ & \\
\hline \multirow[t]{4}{*}{ Attration } & $\$ 1$ & Content of the tourism site is useful & 713 & 834 \\
\hline & $\$ 2$ & Touricm cite s interecting & $\$ 00$ & \\
\hline & \$3 & Tourism site attract my attenton & 315 & \\
\hline & 84 & Pay a lor of attentias to anything a tont this tourism site. & 576 & \\
\hline \multirow[t]{5}{*}{$\begin{array}{l}\text { Customer } \\
\text { Engygement }\end{array}$} & M1 & $\begin{array}{l}\text { Often browse toutism brands on sochal meda (Frobook or } \\
\text { Twisteror Google } \rightarrow \text { ) }\end{array}$ & 738 & 897 \\
\hline & M2 & $\begin{array}{l}\text { Offen like (for facebook), faroritt (for twitter), or }+1 \text { (for } \\
\text { gongle+) poots on my preferred hourime brands on soxtal } \\
\text { mudia }\end{array}$ & .763 & \\
\hline & M3 & $\begin{array}{l}\text { Ofen write comment [for ficebook ot google !) or leave a } \\
\text { reply (for twitter), on ny preferred tourism brand page on } \\
\text { socilal medis }\end{array}$ & .355 & \\
\hline & M4 & 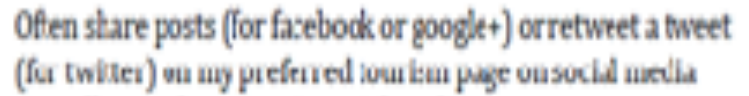 & 396 & \\
\hline & M5 & Overall.activly ergage in sodal modia & 567 & \\
\hline \multirow[t]{4}{*}{ Brand Image } & II & Trist my preetrred tourlsm brands & .514 & .715 \\
\hline & 12 & Brand image correponds to my sef-image in masy respects & 522 & \\
\hline & 13 & My preferred tourtsm brand is superior & .542 & \\
\hline & 14 & My preferred tourtm brand lawe good image & 509 & \\
\hline \multirow[t]{4}{*}{ Brand Loyalty } & L1 & Kemain loyal to my prefsrred tounim brands & .165 & 803 \\
\hline & $\mathrm{L} 2$ & $\begin{array}{l}\text { Regulary support my preferred tourim brands in social } \\
\text { modis }\end{array}$ & 785 & \\
\hline & L3 & $\begin{array}{l}\text { Continue to suppert my prekerred tourism brands in social } \\
\text { media }\end{array}$ & 794 & \\
\hline & 14 & $\begin{array}{l}\text { Sxy positive things about my preferred tourism brands in } \\
\text { sodal media }\end{array}$ & .785 & \\
\hline
\end{tabular}

\subsection{Model Causality Testing}

The regression weights and probability value which indicates its significance is shown in Table 2 and final structural model is shown in Figure 1. The findings concluded that social interaction had significant positive effect $(0.249)$ on $\mathrm{CE}$ and $\mathrm{H}_{1}$ is accepted. $\mathrm{H}_{2}$ is accepted and surveillance has significant effect on $\mathrm{CE}(0.407)$. The regression coefficient of the relationship between attraction and $\mathrm{CE}$ is also significant (0.197) and $\mathrm{H}_{3}$ is accepted. $\mathrm{CE}$ had direct positive effect on brand image $(0.214)$ and brand loyalty (0.423). H4 and H5 is accepted as well. 


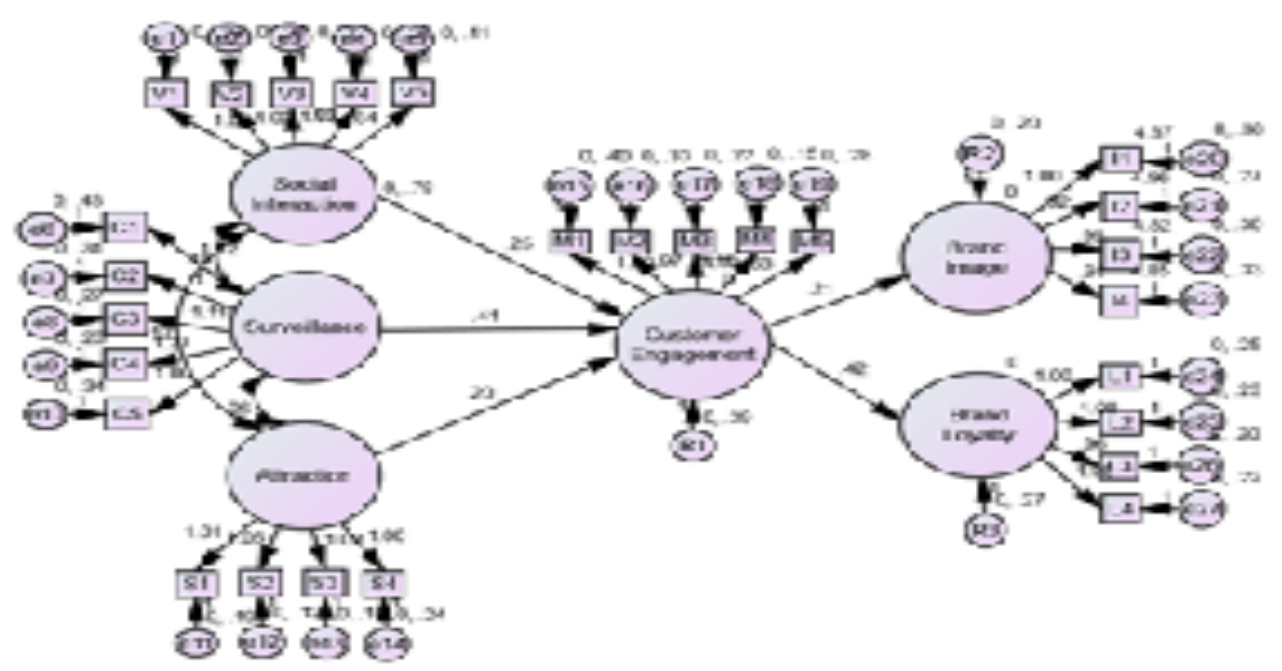

Fig. 1: Final Structural Model

Table 2: Regression Weights and the Probability Value which Indicates its Significance 


\begin{tabular}{|c|c|c|c|c|c|c|}
\hline Paths & & Estimate & $S_{1} E_{1}$ & $C, R$ & P & Result \\
\hline CE & <.- Social Interaction & .249 & .049 & 5.098 & m4 & Supported \\
\hline CE & «.- Surveillance & 407 & .083 & 4.880 & ** & Supported \\
\hline CE & \&. Attraction & 197. & .096 & 2.045 & .041 & Supported \\
\hline Brand Image & $\Leftrightarrow$ CE & .214 & .045 & 4.735 & $\cdots$ & Supported \\
\hline Brand Loyalty & $\Leftrightarrow C E$ & .423 & .051 & 8.285 & $m$ & Supported \\
\hline
\end{tabular}

\section{Discussion}

In the theoretical contributions, we propose a new $\mathrm{CE}$ framework that reflects the interrelationships between motives - information sharing, surveillance and attraction from U\&G theory, and brand performance outcomes in the context of brand image and brand loyalty. This study provides a catalyst for future inquiry, which is required to validate the proposed CE conceptualization and measurement instrument.

As for the managerial contributions, this study has provided valuable insight to the practitioners in planning and implementing more effective CE strategies on SM to achieve better brand performance. The findings revealed that the coefficient value of attraction construct is weak. With that, tourism firms should create more attractive sites, better content and valuable information with is supported with evidence of the services, such as pictures or videos, to improve engagement with customers. Our model also posits that engagement behaviours could be enhance with the use of different SM approaches such as induce customers through continuous promotions or rewards, intensity of interactivity and participation. It is also suggested that SM campaigns should emphasize more on the benefits, values and advantages based on different segment of SM users. Furthermore, customers should be given opportunities to suggest their ideas for new services or service improvement of the tourism firms. Shared-value could be created and enhanced which will increase brand image and brand loyalty.

\section{Conclusion}

Replications of this study in other contexts such as other countries and other industries are recommended to examine the generalizability of the findings and verify the model. Future research could also investigate the influence of $\mathrm{CE}$ in SM on other consumer-based brand performance measurement or even financial performance of the firms.

\section{References}

Arora, P. and Predmore, C.E. (2014). Social Media as a Strategic Tool: Going Beyond the Obvious. Social Media in Strategic Management, Emerald Group Publishing Limited, Bingley, UK.

Blasco-Arcas, L., Hernandez-Ortega, B.I. and Jimenez-Martinez, J. (2016). Engagement platforms: The role of emotions in fostering customer engagement and brand image in interactive media. Journal of Service Theory and Practice, 26(5): 559-589.

Bowden, J.L. (2009). The Process of Customer Engagement: A Conceptual Framework. Journal of Marketing Theory and Practice, 17(1): 63-74.

Brodie, R.J., Ilic, A., Juric, B. and Hollebeek, L. (2013). Consumer Engagement in a Virtual Brand Community: An Exploratory Analysis. Journal of Business Research, 66(1): 105-14. USA.

Burton, G. (2010). Media \& Society - Critical Perspectives, 2nd ed., McGraw-Hill, New York,

Cho, C.H. (1999). How Advertising Works on the WWW: Modified Elaboration Likelihood Model. Journal of Current Issues and Research in Advertising, 21(1): 33-50.

Cvijikj, I.P. and Michahelles, F. (2013). Online Engagement Factors on Facebook Brand Pages. Social Network Analysis and Mining, 3(4): 843-861. 
De Vries, L., Gensler, S. and Leeflang, P.S.H. (2012). Popularity of Brand Posts on Brand Fan Pages: An Investigation of the Effects of Social Media Marketing. Journal of Interactive Marketing, 26(2): 83-91.

De Vries, N.J. and Carlson, J. (2014). Examining the Drivers and Brand Performance Implications of Customer Engagement with Brands in the Social Media Environment. Journal of Brand Management, 21(6): 495-515.

Fortin, D.R. and Ruby R.D. (2005). Interactivity and Vividness Effects on Social Presence and Involvement with a Web-Based Advertisement. Journal of Business Research, 58(3): 387-396.

Gensler, S., Völckner, F., Liu-Thompkins, Y.P. and Wiertz, C. (2013). Managing Brands in the Social Media Environment. Journal of Interactive Marketing, 27(4): 242-256.

Gummerus, J., Veronica, L., Weman, E. and Pihlström, M. (2012). Customer Engagement in a Facebook Brand Community. Management Research Review, 35(9): 857-877.

Harrigan, P., Evers, U., Miles, M. and Daly, T. (2017). Customer engagement with tourism social media brands. Tourism Management, 59(1): 597-609.

Hollebeek, L.D. (2011). Demystifying Customer Brand Engagement: Exploring the Loyalty Nexus. Journal of Marketing Management, 27(7-8): 785-807.

Hollebeek, L.D., Glynn, M.S. and Brodie, R.J. (2014). Consumer Brand Engagement in Social Media: Conceptualization, Scale Development and Validation. Journal of Interactive Marketing, 28(2): 149-165.

Humphreys, L. and Wilken, R. (2015). Social media, small businesses, and the control of information. Information, Communication \& Society, 18(13): 295-309.

Kam, F.S., King, C. and Sparks, B.A. (2014). Customer engagement with tourism brands: Scale development and validation. Journal of Hospitality \& Tourism Research, 38(3): 304-329.

Kam, F.S., King, C., Sparks, B.A. and Wang, Y. (2016). Enhancing customer relationships with retail service brands: The role of customer engagement. Journal of Service Management, 27(2): 170-193.

Kaplan, R.S. and Norton, D.P. (1992). The Balanced Scorecard - Measures That Drive Performance. Harvard Business Review, 70(1): 71-80.

Katz, E., Blumler, J. and Gurevitch, M. (1974). Utilization of mass communication by the individual. In Blumler, J. and Katz, E. (Eds.), The uses of mass communication: Current perspectives on gratifications research (pp. 19-34). Sage, Beverly Hills, CA.

Keller, K.L. (1993). Conceptualizing, Measuring, and Managing Customer-Based Brand Equity. Journal of Marketing, 57(1): 1-22.

Keller, K.L. and Lehmann, D.R. (2003). How Do Brands Create Value?. Marketing Management, 12(3): 26-31.

Khan, I., Rahman, Z. and Fatma, M.(2016). The role of customer brand engagement and brand experience in online banking. International Journal of Bank Marketing, 34(7): 1025-1041.

Munoz, T. and Kumar, S. (2004). Brand metrics: Gauging and linking brands with business performance. Journal of Brand Management, 11(5): 381-387.

Muntinga, D.G., Moorman, M. and Smit, E.G. (2011). Introducing COBRAs: Exploring Motivations for Brand-Related Social Media Use. International Journal of Advertising, 30(1): 13-46.

Pallant, J. (2007). SPSS Survival Manual. Open University Press, Maidenhead.

Perez, R.C., Mafe, C.R. and Blas, S.S. (2014). Determinants of User Behaviour and Recommendation in Social Networks. Industrial Management \& Data Systems, 114(9): 1477-1498.

So, K. K. F., King, C. and Sparks, B. (2014). Customer engagement with tourism Brands: Scale development and validation. Journal of Hospitality \& Tourism Research, 38(3): 304-329.

So, K.K.F., King, C., Sparks, B.A. and Wang, Y. (2016). Enhancing customer relationships with retail service brands. Journal of Service Management, 27(2): 170-193.

Scholer, A.A. and Higgins, E.T. (2009). Exploring the Complexities of Value creation: the Role of Engagement Strength. Journal of Consumer Psychology, 19(1):137-143.

Steuer, J. (1992). Defining Virtual Reality: Dimensions Determining Telepresence. Journal of Communication, 42(4): 73-93.

Taylor, D.G., Lewin, J.E. and Strutton, D. (2011). Friends, Fans, and Followers: Do Ads Work on Social Networks?. Journal of Advertising Research, 51(1): 258-275. 
TripAdvisor (2017). TripAdvisor Reaches Half A Billion Reviews And Opinions And Counting. See also URL https://tripadvisor.mediaroom.com/2017-04-19-TripAdv- isor-Reaches-Half-A-BillionReviews-And-Opinions-And-Counting.

Trivedi, H., Vadher, D. and Shah, D. (2010). Brand Performance Measurement through Balanced Scorecard Model. 1st ed. [ebook] Mudra Institute of Communications, Ahmedabad Gujarat, India. See also http://www.marketing-trends-congress.com/archives/20 10/Materiali/Paper/Fr/ Trivedi_Vadher_Shah.pdf.

Van Doorn, J., Lemon, K.N., Mittal, V., Nass, S., Pick, D., Pirner, P. and Verhoef, P.C. (2010). Customer Engagement Behavior: Theoretical Foundations and Research Directions. Journal of Service Research, 13(3): 253-266.

Vivek, S.D., Beatty, S.E. and Morgan, R.M. (2012). Customer engagement: Exploring customer relationships beyond purchase. Journal of Marketing Theory and Practice, 20(2): 122-146.

Wang, Z. and Hyun, G.K. (2017). Can Social Media Marketing Improve Customer Relationship Capabilities and Firm Performance? Dynamic Capability Perspective. Journal of Interactive Marketing, 39(3):15-26.

Whiting, A. and Williams, D. (2013). Why People Use Social Media: A Uses and Gratifications Approach. Qualitative Market Research: An International Journal, 16(4): 362-369.

Woisetschläger, D.M., Hartleb, V. and Blut, M. (2008). How to make brand communities work: antecedents and consequences of consumer participation. Journal of Relationship Marketing, 7(3): $237-256$. 